\title{
Antibiotic Therapy for Children with Diarrhea in a Low-Resource Setting: A Syndromic Approach
}

This article was published in the following Dove Press journal:

Pediatric Health, Medicine and Therapeutics

\author{
Subhashchandra Daga' \\ Achla Daga ${ }^{2}$ \\ Sameer Mhatre' \\ 'Department of Pediatrics, MIMER \\ Medical College, Talegaon Dabhade \\ 410507, India; ${ }^{2}$ Department of \\ Community Medicine, Pacific Medical \\ College, Udaipur 3/300I, India
}

\begin{abstract}
Objective: To compare age and protein-energy malnutrition (PEM) - the predispositions and fever and abnormal leukocyte count (ALC) - the SIRS criteria - in hospitalized children with and without diarrhea.

Design: A prospective case-control study.

Setting: A pediatric ward of a general hospital in a low-resource setting.

Participants: Totally, 445 consecutive admissions to the pediatric ward of a general hospital over a period of 1 year were included in this prospective case-control study; hemodynamically unstable subjects (11) were excluded.

Interventions: Age, PEM, fever, and ALC were assessed in 59 patients with diarrhea and compared with 375 control patients without diarrhea. Odds ratios with confidence intervals were determined; the chi-square test and binary logistic regression analysis were also performed.
\end{abstract}

Main Outcome Measures: Associations of diarrhea with age, PEM, fever and ALC singly and various combinations of predispositions and SIRS parameters.

Results: Infancy and ALC were significantly associated with diarrhea. PEM or fever alone was not significantly associated with diarrhea; however, the probability of developing diarrhea was significantly higher when a combination of ALC and PEM was observed The combination of infancy, PEM, and ALC carried a sensitivity of $81 \cdot 36 \%$; for other combinations, sensitivity varied between $70 \%$ and $80 \%$. The combination of infancy and ALC had the lowest sensitivity (59.32\%) but the best specificity $(61 \cdot 07 \%)$.

Conclusion: The association/presence of a combination of SIRS parameters (fever and ALC) and predispositions (infancy and PEM) in children with diarrhea may help in deciding whether antibiotic therapy should be initiated.

Keywords: diarrhea in children, sepsis in children, SIRS in diarrhea, child mortality

\section{Introduction}

While diarrhea mortality rates have dropped by 75\% from 1980 to 2008 , they remain unacceptably high. ${ }^{1}$ A reduction in diarrheal deaths is essential for attaining the United Nations' (UN) sustainable development goal 3.2 of reducing under-5 mortality to at least as low as 25 per 1000 live births. Sepsis, an important link between diarrheal illness and death, often requires urgent attention. ${ }^{2,3}$ In the absence of good laboratory support, the decision to initiate antibiotic therapy for presumed sepsis in cases of diarrhea is often guided by the presence of systemic inflammatory response syndrome (SIRS) criteria, alongside several predispositions for sepsis. Sepsis is defined as the presence of two or more SIRS criteria in a setting of presumed or documented infection. ${ }^{4}$ A distinct feature of pediatric SIRS is
Correspondence: Subhashchandra Daga Department of Pediatrics, Pacific Medical College, Udaipur 3/300I, India Tel +9l 9960522259

Email dagasubhash49@gmail.com 
a mandatory requirement of either abnormal temperature or abnormal leukocyte count (ALC) for diagnosis; ${ }^{5}$ for these reasons, this study included assessments of fever and ALC. Similarly, age (infancy), and protein-energy malnutrition (PEM) were included since they are known predisposing factors. ${ }^{6-8}$ An age-and sex-adjusted study on the incidence and outcomes of pediatric sepsis found that the incidence was highest in infants $(5 \cdot 16$ per 1000 vs $0 \cdot 2$ per 1000 in older children). ${ }^{6}$ It has also been found that children at risk of becoming severely ill with diarrhea were significantly more likely to be bacteremic than those with non-severe illness (26\% versus $9 \%$ ). ${ }^{7}$ Similarly, studies exploring risk factors for fatal diarrhea have observed that children with severe illness are significantly more likely to be malnourished. ${ }^{8}$

The present study was conducted to determine whether diarrhea, particularly in underserved children, enhance the decision to initiate antibiotic therapy in presence of a combination with SIRS criteria, namely fever and ALC, and predispositions, such as infancy and PEM. With poor access to the hospital care, it may be a matter of grave concern should their condition worsen.

\section{Methods}

This prospective, case-control study enrolled 434 consecutive admissions to the pediatric in-patient department of a general hospital attached to a rural medical college. This hospital almost exclusively caters to the lower or lowermiddle classes from the surrounding rural area. Hospital stays and medical consultations at this hospital are free of charge; however, medicines and investigations are chargeable. Eleven subjects with diarrhea were excluded from this study as they were found to be hemodynamically unstable. Overall, the following parameters were assessed in 59 patients with diarrhea and 375 control patients without diarrhea: infancy, fever, ALC, PEM, and all possible combinations. Fever was defined as an axillary temperature of more than $38^{\circ} \mathrm{C}$, and ALC was based on ageappropriate white cell counts. ${ }^{5}$ Nutritional status was determined by weight-for-age charts provided by the Indian Academy of Paediatrics. ${ }^{9}$ Blood culture, stool culture, CRP and procalcitonin studies were not performed.

The odds of diarrhea were assessed by calculation of odds ratios (OR) with confidence intervals (CI). The association of variables with diarrhea was assessed by the chi-square test. A p-value was considered statistically significant at $\leq 0 \cdot 05$. Binary logistic regression analysis was performed to identify any significant predictors of diarrhea, with infancy, PEM, ALC, and fever all listed as independent (predictor) variables; the combinations of these variables were also assessed in a similar manner. A scientific format was used to display p-values less than 0.0001 in exponential notation, replacing part of the number with E-n. Microsoft Excel Office 365 was used for data entry and PSPP version $1 \cdot 0 \cdot 1$ was used for statistical analysis.

\section{Results}

Infants formed a significantly higher proportion (Table 1) of those patients with diarrhea (34.0\%) compared with children up to 12 years (10.8\%; p-value 0.0000106); the OR of diarrhea (Table 2) was also high among this group (OR 4.265, 95\% CI 2·217-8·205). Similarly, ALC had a significant association with diarrhea (p-value 0.0363 ) and a high odds ratio (OR 1·873, 95\% CI 1·076-3.262). Individually, PEM and fever had no significant association with diarrhea. Among all independent variables or their combinations, only ALC and the combination of ALC and PEM had a high probability for diarrhea (Table 3). For ALC alone, this was reflected in the following results: Wald $=4 \cdot 208$, p-value $0 \cdot 0402$, and $\mathrm{OR}=2 \cdot 557 ; 95 \% \mathrm{CI}$ 2.098-8.089. The values for ALC and PEM were Wald $=5.912$, p-value 0.0150 and $\mathrm{OR}=1 \cdot 83 ; 95 \% \mathrm{CI}$ 0.046-0.719. Among all combinations, the combination of infancy, PEM, and ALC had the highest sensitivity

Table I Prevalence of Diarrhea by Age

\begin{tabular}{|c|c|c|c|c|}
\hline \multirow[t]{2}{*}{ Age (Years) } & & \multicolumn{2}{|c|}{ Diarrhea } & \multirow[t]{2}{*}{ Total } \\
\hline & & Yes & No & \\
\hline$<1$ & $\begin{array}{l}\text { No. } \\
\%\end{array}$ & $\begin{array}{l}18 \\
34.0 \%\end{array}$ & $\begin{array}{l}35 \\
66.0 \%\end{array}$ & $\begin{array}{l}53 \\
100.0 \%\end{array}$ \\
\hline $\mathrm{I}-5$ & $\begin{array}{l}\text { No. } \\
\%\end{array}$ & $\begin{array}{l}29 \\
19.1 \%\end{array}$ & $\begin{array}{l}123 \\
80.9 \%\end{array}$ & $\begin{array}{l}152 \\
100.0 \%\end{array}$ \\
\hline $5-10$ & $\begin{array}{l}\text { No. } \\
\%\end{array}$ & $\begin{array}{l}9 \\
7.1 \%\end{array}$ & $\begin{array}{l}118 \\
92.9 \%\end{array}$ & $\begin{array}{l}127 \\
100.0 \%\end{array}$ \\
\hline $10-15$ & $\begin{array}{l}\text { No. } \\
\%\end{array}$ & $\begin{array}{l}3 \\
3.1 \%\end{array}$ & $\begin{array}{l}93 \\
96.9 \%\end{array}$ & $\begin{array}{l}96 \\
100.0 \%\end{array}$ \\
\hline$\geq 15$ & $\begin{array}{l}\text { No. } \\
\%\end{array}$ & $\begin{array}{l}0 \\
0.0 \%\end{array}$ & $\begin{array}{l}6 \\
100.0 \%\end{array}$ & $\begin{array}{l}6 \\
100.0 \%\end{array}$ \\
\hline Total & $\begin{array}{l}\text { No. } \\
\%\end{array}$ & $\begin{array}{l}59 \\
13.6 \%\end{array}$ & $\begin{array}{l}375 \\
86.4 \%\end{array}$ & $\begin{array}{l}434 \\
100.0 \%\end{array}$ \\
\hline Chi-Square Test & Value & $d f$ & $\mathrm{P}$-value & Association is \\
\hline Pearson Chi-Square & 37.092 & 4 & I.72E-07 & Significant \\
\hline
\end{tabular}


Table 2 Association of All Variables with Diarrhea Among the Assessed Cases

\begin{tabular}{|c|c|c|c|c|c|c|c|c|}
\hline \multirow[t]{3}{*}{ Variables } & & \multicolumn{4}{|c|}{ Diarrhea } & \multicolumn{3}{|c|}{ Odds Ratio } \\
\hline & & \multicolumn{2}{|l|}{ Yes } & \multirow{2}{*}{\multicolumn{2}{|c|}{ No }} & \multirow[t]{2}{*}{ Value } & \multicolumn{2}{|l|}{$95 \% \mathrm{Cl}$} \\
\hline & & & & & & & Lower & Upper \\
\hline \multirow[t]{2}{*}{ Age below I year } & $\begin{array}{l}\text { Yes }(n=53) \\
\text { No }(n=38 I)\end{array}$ & $\begin{array}{l}18 \\
41\end{array}$ & $\begin{array}{l}34.0 \% \\
10.8 \%\end{array}$ & $\begin{array}{l}35 \\
340\end{array}$ & $\begin{array}{l}66.0 \% \\
89.2 \%\end{array}$ & 4.265 & 2.217 & 8.205 \\
\hline & $\chi^{2}$ & 19.392 & $\mathrm{p}$-value & $1.06 \mathrm{E}-05$ & \multicolumn{4}{|c|}{ Association is Significant } \\
\hline \multirow[t]{2}{*}{ PEM } & $\begin{array}{l}\text { Yes }(n=187) \\
\text { No }(n=247)\end{array}$ & $\begin{array}{l}26 \\
33\end{array}$ & $\begin{array}{l}13.9 \% \\
13.4 \%\end{array}$ & $\begin{array}{l}161 \\
214\end{array}$ & $\begin{array}{l}86.1 \% \\
86.6 \%\end{array}$ & 1.047 & 0.602 & 1.821 \\
\hline & $\chi^{2}$ & 0.0000 & $\mathrm{p}$-value & 0.982 & \multicolumn{4}{|c|}{ Association is Not Significant } \\
\hline \multirow[t]{2}{*}{ Fever } & $\begin{array}{l}\text { Yes }(n=250) \\
\text { No }(n=184)\end{array}$ & $\begin{array}{l}36 \\
23\end{array}$ & $\begin{array}{l}14.4 \% \\
12.5 \%\end{array}$ & $\begin{array}{l}214 \\
161\end{array}$ & $\begin{array}{l}85.6 \% \\
87.5 \%\end{array}$ & 1.178 & 0.671 & 2.065 \\
\hline & $\chi^{2}$ & 0.184 & $\mathrm{p}$-value & 0.668 & \multicolumn{4}{|c|}{ Association is Not Significant } \\
\hline \multirow[t]{2}{*}{ ALC } & $\begin{array}{l}\text { Yes }(n=150) \\
\text { No }(n=284)\end{array}$ & $\begin{array}{l}28 \\
31\end{array}$ & $\begin{array}{l}18.7 \% \\
10.9 \%\end{array}$ & $\begin{array}{l}122 \\
253\end{array}$ & $\begin{array}{l}81.3 \% \\
89.1 \%\end{array}$ & 1.873 & 1.076 & 3.262 \\
\hline & $\chi^{2}$ & 4.382 & $\mathrm{p}$-value & 0.0363 & \multicolumn{4}{|c|}{ Association is Significant } \\
\hline
\end{tabular}

Notes: $\chi^{2}=$ Chi-Square value. Pearson's Ch-Square Test with Continuity Correction applied to all tables.

Abbreviations: ALC, Abnormal Leukocyte Count; PEM, Protein Energy Malnutrition; Cl, Confidence Interval.

Table 3 Binary Logistic Regression Analysis with Diarrhea as a Dependent Variable

\begin{tabular}{|c|c|c|c|c|c|c|c|}
\hline \multicolumn{8}{|l|}{ Dependent Variable Encoding } \\
\hline \multirow{3}{*}{\multicolumn{2}{|c|}{$\begin{array}{l}\text { Diarrhea } \\
\text { Yes } \\
\text { No }\end{array}$}} & \multirow{3}{*}{\multicolumn{6}{|c|}{$\begin{array}{l}\text { Internal Value } \\
1 \\
0\end{array}$}} \\
\hline & & & & & & & \\
\hline & & & & & & & \\
\hline \multicolumn{2}{|l|}{ Model Summary } & \multirow{3}{*}{\multicolumn{6}{|c|}{$\begin{array}{l}\text { Nagelkerke R Square } \\
0.148\end{array}$}} \\
\hline-2 Log likelihood & & & & & & & \\
\hline 308.394 & & & & & & & \\
\hline \multirow[t]{2}{*}{ Variables } & \multirow[t]{2}{*}{ B } & \multirow[t]{2}{*}{ S.E. } & \multirow[t]{2}{*}{ Wald value } & \multirow[t]{2}{*}{$\mathrm{p}$-value } & \multirow[t]{2}{*}{$\operatorname{Exp}(B)$} & \multicolumn{2}{|c|}{$95.0 \%$ C.I.for $\operatorname{Exp}(B)$} \\
\hline & & & & & & Lower & Upper \\
\hline Age < I year (Yes) & 1.098 & 0.630 & 3.042 & 0.081 & 2.999 & 0.873 & 10.303 \\
\hline PEM (Yes) & -0.194 & 0.557 & 0.122 & 0.727 & 0.823 & 0.276 & 2.453 \\
\hline ALC (Yes) & 0.939 & 0.458 & 4.208 & 0.0402 & 2.557 & 1.043 & 6.269 \\
\hline Fever (Yes) & -0.371 & 0.475 & 0.611 & 0.434 & 0.690 & 0.272 & 1.750 \\
\hline Age $<$ I year by fever & -0.726 & 0.921 & 0.621 & 0.431 & 0.484 & 0.080 & 2.944 \\
\hline Fever by PEM & 1.100 & 0.705 & 2.434 & 0.119 & 3.003 & 0.754 & 11.956 \\
\hline ALC by Age $<$ I year & 0.259 & 0.876 & 0.088 & 0.767 & 1.296 & 0.233 & 7.215 \\
\hline ALC by PEM & -1.700 & 0.699 & 5.912 & 0.0150 & 0.183 & 0.046 & 0.719 \\
\hline Age $<$ I year by fever by PEM & 1.133 & 1.226 & 0.853 & 0.356 & 3.104 & $0.28 \mathrm{I}$ & 34.341 \\
\hline Age less Than I year by fever by PEM by ALC & 0.918 & 1.377 & 0.445 & 0.505 & 2.504 & 0.169 & 37.188 \\
\hline Constant & -2.331 & 0.374 & 38.796 & 0.000 & 0.097 & & \\
\hline
\end{tabular}

Abbreviations: ALC, Abnormal Leukocyte Count; PEM, Protein Energy Malnutrition.

$(81 \cdot 36 \%)$. The sensitivity of other combinations (fever and

ALC, fever and infancy, ALC and PEM, and fever and PEM) varied between $70 \%$ and $80 \%$, in descending order
(Table 4). The combination of infancy and ALC had the lowest sensitivity $(59 \cdot 32 \%)$ but had the best specificity $(61 \cdot 07 \%)$. 
Table 4 Efficacy of Various Combinations of SIRS Criteria and Predispositions for Sepsis

\begin{tabular}{|c|c|c|c|c|c|c|c|c|c|c|}
\hline \multirow[t]{3}{*}{ Variables } & & \multicolumn{4}{|c|}{ Diarrhea } & & \multirow{2}{*}{\multicolumn{4}{|c|}{ Diagnostic Efficacy }} \\
\hline & & \multicolumn{2}{|l|}{ Yes } & \multicolumn{2}{|l|}{ No } & & & & & \\
\hline & & No. & $\%$ & No. & $\%$ & & Sensitivity & Specificity & PLR & NLR \\
\hline Infancy+ Fever & $\begin{array}{l}\text { Yes }(n=276) \\
\text { No }(n=158)\end{array}$ & $\begin{array}{l}44 \\
15 \\
\chi^{2}\end{array}$ & $\begin{array}{l}15.9 \% \\
9.5 \% \\
3.029\end{array}$ & $\begin{array}{l}232 \\
143 \\
P \text {-value }\end{array}$ & $\begin{array}{l}84.1 \% \\
90.5 \% \\
0.082\end{array}$ & $\begin{array}{l}\text { Value } \\
\text { L95\% Cl } \\
\text { U95\% Cl }\end{array}$ & $\begin{array}{l}74.58 \% \\
61.56 \% \\
85.02 \%\end{array}$ & $\begin{array}{l}38.13 \% \\
33.19 \% \\
43.26 \%\end{array}$ & $\begin{array}{l}1.205 \\
1.018 \\
1.427\end{array}$ & $\begin{array}{l}0.667 \\
0.423 \\
1.052\end{array}$ \\
\hline Fever+ PEM & $\begin{array}{l}\text { Yes }(n=324) \\
\text { No }(n=\mid 10)\end{array}$ & $\begin{array}{l}42 \\
17 \\
\chi^{2}\end{array}$ & $\begin{array}{l}13.0 \% \\
15.5 \% \\
0.248\end{array}$ & $\begin{array}{l}282 \\
93 \\
p \text {-value }\end{array}$ & $\begin{array}{l}87.0 \% \\
84.5 \% \\
0.619\end{array}$ & $\begin{array}{l}\text { Value } \\
\text { L95\% Cl } \\
\text { U95\% Cl }\end{array}$ & $\begin{array}{l}71.19 \% \\
57.92 \% \\
82.24 \%\end{array}$ & $\begin{array}{l}24.80 \% \\
20.51 \% \\
29.49 \%\end{array}$ & $\begin{array}{l}0.947 \\
0.797 \\
1.125\end{array}$ & $\begin{array}{l}1.162 \\
0.750 \\
1.801\end{array}$ \\
\hline Infancy+ ALC & $\begin{array}{l}\text { Yes }(n=|8|) \\
\text { No }(n=253)\end{array}$ & $\begin{array}{l}35 \\
24 \\
\chi^{2}\end{array}$ & $\begin{array}{l}19.3 \% \\
9.5 \% \\
7.898\end{array}$ & $\begin{array}{l}146 \\
229 \\
p \text {-value }\end{array}$ & $\begin{array}{l}80.7 \% \\
90.5 \% \\
0.005^{*}\end{array}$ & $\begin{array}{l}\text { Value } \\
\text { L95\% Cl } \\
\text { U95\% Cl }\end{array}$ & $\begin{array}{l}59.32 \% \\
45.75 \% \\
71.93 \%\end{array}$ & $\begin{array}{l}61.07 \% \\
55.93 \% \\
66.03 \%\end{array}$ & $\begin{array}{l}1.524 \\
1.191 \\
1.949\end{array}$ & $\begin{array}{l}0.666 \\
0.484 \\
0.916\end{array}$ \\
\hline $\mathrm{ALC}+\mathrm{PEM}$ & $\begin{array}{l}\text { Yes }(n=253) \\
\text { No }(n=181)\end{array}$ & $\begin{array}{l}43 \\
16 \\
\chi^{2}\end{array}$ & $\begin{array}{l}17.0 \% \\
8.8 \% \\
5.302\end{array}$ & $\begin{array}{l}210 \\
165 \\
P \text {-value }\end{array}$ & $\begin{array}{l}83.0 \% \\
91.2 \% \\
0.0213^{*}\end{array}$ & $\begin{array}{l}\text { Value } \\
\text { L95\% Cl } \\
\text { U95\% Cl }\end{array}$ & $\begin{array}{l}72.88 \% \\
59.73 \% \\
83.64 \%\end{array}$ & $\begin{array}{l}44.00 \% \\
38.91 \% \\
49.19 \%\end{array}$ & $\begin{array}{l}1.301 \\
1.087 \\
1.558\end{array}$ & $\begin{array}{l}0.616 \\
0.399 \\
0.951\end{array}$ \\
\hline Infancy+ PEM+ Fever & $\begin{array}{l}\text { Yes }(n=34 I) \\
\text { No }(n=93)\end{array}$ & $\begin{array}{l}48 \\
11 \\
\chi^{2}\end{array}$ & $\begin{array}{l}14.1 \% \\
11.8 \% \\
0.152\end{array}$ & $\begin{array}{l}293 \\
82 \\
\mathrm{P} \text {-value }\end{array}$ & $\begin{array}{l}85.9 \% \\
88.2 \% \\
0.696\end{array}$ & $\begin{array}{l}\text { Value } \\
\text { L95\% Cl } \\
\text { U95\% Cl }\end{array}$ & $\begin{array}{l}81.36 \% \\
69.09 \% \\
90.31 \%\end{array}$ & $\begin{array}{l}21.87 \% \\
17.79 \% \\
26.40 \%\end{array}$ & $\begin{array}{l}1.041 \\
0.911 \\
1.190\end{array}$ & $\begin{array}{l}0.853 \\
0.484 \\
1.502\end{array}$ \\
\hline Infancy+ PEM+ ALC & $\begin{array}{l}\text { Yes }(n=271) \\
\text { No }(n=163)\end{array}$ & $\begin{array}{l}46 \\
13 \\
\chi^{2}\end{array}$ & $\begin{array}{l}17.0 \% \\
8.0 \% \\
6.271\end{array}$ & $\begin{array}{l}225 \\
150 \\
P \text {-value }\end{array}$ & $\begin{array}{l}83.0 \% \\
92.0 \% \\
0.0123 *\end{array}$ & $\begin{array}{l}\text { Value } \\
\text { L95\% Cl } \\
\text { U95\% Cl }\end{array}$ & $\begin{array}{l}77.97 \% \\
65.27 \% \\
87.71 \%\end{array}$ & $\begin{array}{l}31.47 \% \\
26.80 \% \\
36.43 \%\end{array}$ & $\begin{array}{l}1.138 \\
0.977 \\
1.324\end{array}$ & $\begin{array}{l}0.700 \\
0.424 \\
1.158\end{array}$ \\
\hline Fever + ALC & $\begin{array}{l}\text { Yes }(n=304) \\
\text { No }(n=130)\end{array}$ & $\begin{array}{l}47 \\
12 \\
\chi^{2}\end{array}$ & $\begin{array}{l}15.5 \% \\
9.2 \% \\
2.502\end{array}$ & $\begin{array}{l}257 \\
118 \\
p \text {-value }\end{array}$ & $\begin{array}{l}84.5 \% \\
90.8 \% \\
0.114\end{array}$ & $\begin{array}{l}\text { Value } \\
\text { L95\% Cl } \\
\text { U95\% Cl }\end{array}$ & $\begin{array}{l}79.66 \% \\
67.17 \% \\
89.02 \%\end{array}$ & $\begin{array}{l}36.86 \% \\
32.16 \% \\
41.75 \%\end{array}$ & $\begin{array}{l}1.262 \\
1.087 \\
1.464\end{array}$ & $\begin{array}{l}0.552 \\
0.328 \\
0.929\end{array}$ \\
\hline
\end{tabular}

Notes: L95\% Cl: Lower 95\% Cl; U95\% Cl: Upper 95\% Cl, *indicates significant association.

Abbreviations: PLR, Likelihood ratio of positive test; NLR, Likelihood ratio of negative test.

\section{Discussion}

The present study suggests that antibiotics may be indicated in subjects with diarrhea in the presence of a combination of predispositions (such as infancy and malnutrition) and SIRS indicators (such as fever and ALC) (Table 4), when a definitive diagnosis of accompanying sepsis cannot be made and the anticipated risk of death is high. The study demonstrates that infancy has a significant association with diarrhea and a high OR for the development of diarrhea. Similarly, PEM, the other predisposing factor assessed in this study, in combination with fever and ALC was a good predictor of diarrhea. Therefore, infancy and malnutrition may be included as predispositions under the PIRO (predisposition, insult, response, organ dysfunction) concept of sepsis in deciding the treatment of diarrhea in underserved communities where health-seeking is poor, transportation is difficult and, infrastructure is sub-optimal. ${ }^{11}$

The revised recommendations for diarrhea management, WHO/UNICEF and USAID ${ }^{10}$ suggested the selective use of antibiotics along with an oral rehydration solution, continued feeding and zinc supplementation. It is noteworthy that antimicrobial properties of zinc are unfolding and effectiveness of zinc in treatment of diarrhea may also be due to its antimicrobial property. Macrophages have been visualized are to deploy zinc to clear bacterial infections. ${ }^{12}$ It is also observed that zinc completely inhibited the growth of all the tested enteric bacterial pathogens isolated from diarrheal stool specimens. ${ }^{13}$ A study from Nigeria ${ }^{14}$ observed that the prevalence of zinc deficiency in the subjects $(47.0 \%)$ with diarrhea was significantly higher than $32.0 \%$ in the controls $(P=0.030)$.

The presence of SIRS prompts an immediate search for both infection, as its possible cause, and organ dysfunction, as a possible companion; the presence of SIRS therefore indicates a diagnosis of "possible sepsis." "I In a study of 3708 subjects, $2527(68 \%)$ met the criteria for SIRS ${ }^{13}$ and, among the patients with SIRS, 649 (26\%) developed sepsis, 467 (18\%) developed severe sepsis, and 110 (4\%) 
developed septic shock. There were also stepwise increases in mortality rates in the following hierarchy: SIRS (7\% mortality), sepsis (16\%), severe sepsis (20\%), and septic shock (46\%); therefore, relying on SIRS as an indicator of sepsis to start antibiotics, especially in lowresource areas where a confirmation of sepsis may be difficult to obtain, appears to be justified.

It is also observed that SIRS components such as fever, tachypnea, tachycardia, and increased WBC count are consistent features of critical illnesses induced by infection; indeed, the odds of at least two of them being present when an infection causes life-threatening organ dysfunctions are more than seven to one. ${ }^{16}$ SIRS is a sensitive parameter for identifying children who progress to death, even with its low specificity (15\%). ${ }^{15}$ A loss of sensitivity would mean a significant loss of diagnoses, resulting in a large number of deaths in underserved communities due to a lack of proper treatment in the early stages of disease. Therefore, SIRS is an appropriate screening strategy for early diagnosis and treatment of pediatric sepsis, particularly in resource-constrained scenarios where many of the laboratory test results are not routinely available.

The PIRO system previously mentioned is a proposed staging system of an acute illness that incorporates an assessment of baseline susceptibility (predisposition), insult (documented infection vs no infection), magnitude of host response to that insult, and the extent of organ dysfunction. It is suggested that the PIRO staging of sepsis, similar to malignant disease staging (TNM staging), might be useful. Although the diagnosis of infection ideally requires the identification of a pathogen, the magnitude of host response is quantified using a sepsis score and the degree of organ dysfunction is quantified by using the multiple organ dysfunction score. ${ }^{17}$ Also, whilst this study included hemodynamically stable inpatients, the findings may be particularly useful in deciding on antibiotic administration at an early stage, typically in the outpatient department.

Strengths and limitations of this study: Sepsis, an important link between diarrheal illness and death, often requires urgent attention. In the absence of good laboratory support, the decision to initiate antibiotic therapy for presumed sepsis in cases of diarrhea is not full-proof. In such situations, a combination with SIRS criteria, namely fever and ALC, and predispositions, such as infancy and PEM, enhance the decision to initiate antibiotic therapy. In locations where blood counts can be performed, the following combinations may be useful: infancy, PEM and ALC; ALC and fever; ALC and PEM. When blood counts are not available, fever and PEM and fever and infancy - although with lower sensitivity - may be useful in initiating antibiotic treatment. This case-control analysis is matched for only age; other covariates should have been included.

\section{Ethics}

The study had the approval of the ethics committee of the MIMER Medical College and Hospital, Talegaon Dabhade and, parental or legal guardian's written informed consent was obtained. The study was in accordance with the Declaration of Helsinki.

\section{Funding}

No funding received.

\section{Disclosure}

The authors report no conflicts of interest in this work.

\section{References}

1. Black RE, Cousens S, Hohnson HL, et al. Global, regional and national causes of child mortality in 2008: a systematic analysis. Lancet. 2010;375:1969-1987. doi:10.1016/S0140-6736(10)60549-1

2. Struelens MJ, Bennish ML, Mondal G, Wojtyniak BJ. Bacteremia during diarrhea: incidence, aetiology, risk factors, and outcome. Am J Epidemiol. 1991;133:451-459. doi:10.1093/oxfordjournals.aje.a115912

3. Bhutta ZA, Punjwani N, Lindblad BS. Concomitant bacteraemia as a risk factor for diarrhoeal disease mortality in Karachi: a case-control study of hospitalized children. Acta Paediatr. 1996;85:809-813. doi:10.1111/j.1651-2227.1996.tb14156.x

4. Watson RS, Carcillo JA. Scope and epidemiology of pediatric sepsis. Pediatr Cri Care Med. 2005;6:S3-S5. doi:10.1097/01.PCC.000016 1289.22464.C3

5. Goldstein B, Giroir B, Randolph A. International pediatric sepsis consensus conference: definitions for sepsis and organ dysfunction in pediatrics. Pediatr Crit Care Med. 2005;6:2-8. doi:10.1097/01. PCC.0000149131.72248.E6

6. Watson RS, Carcillo JA, Linde-zwirble WT, Clermont G, Lidicker J, Angus DC. The epidemiology of severe sepsis in children in the United States. Am J Respir Crit Care Med. 2003;167(5):695-701. doi:10.1164/rccm.200207-682OC

7. Lee LA, Dogore R, Redd SC, et al. Severe illness in African children with diarrhoea: implications for case management strategies. Bull World Health Organ. 1995;73:779-785.

8. Chisti MJ, Saha S, Roy CN, Salam MA. Predictors of bacteremia in infants with diarrhea and systemic inflammatory response syndrome attending an urban diarrheal treatment center in a developing country. Pediatr Crit Care Med. 2010;11:92-97. doi:10.1097/PCC.0b013e3181b063e1

9. Report of the nutrition sub-committee of the indian academy of pediatrics. Indian Pediatr. 1972;9:360.

10. Diarrhoea/Health/UNICEF. 2012. Available from: https://data.unicef. org/topic/child-health/diarrhoeal-disease/. Accessed February 2019.

11. Opal SM. Concept of PIRO as a new conceptual framework to understand sepsis. Pediatr Crit Care Med. 2005;6:S55-S60. doi:10.1097/01.PCC.0000161580.79526.4C

12. Stocks CJ, Phan M, Maud E, et al. Uropathogenic Escherichia coli employ both evasion and resistance to subvert innate immune-mediated zinc toxicity for dissemination. Proc Natl Acad Sci. 2019:201820870. doi:10.1073/pnas.1820870116 
13. Faiz U, Butt T, Satti L, Hussain W, Hanif F. Efficacy of zinc as an antibacterial agent against enteric bacterial pathogens. J Ayub Med Coll Abbottabad. 2011;23(2):18-21.

14. Afolabi OF, Saka AO, Ojuawo A, Biliaminu SA. Serum zinc levels of hospitalized children with acute diarrhea differ by the isolated viruses. Int J Health Sci (Qassim). 2019;13(5):4-10.

15. Simpson SQ. SIRS in the time of sepsis-3. Chest. 2018;153:34-38. doi:10.1016/j.chest.2017.10.006
16. Rangel-frausto MS, Pittet D, Costigan M, Hwang T, Davis CS, Wenzel RP. The natural history of the systemic inflammatory response syndrome (SIRS): A prospective study. JAMA. 1995;273:117-123. doi:10.1001/jama.1995.03520260039030

17. Posadas-calleja JG, Stelfox HT, Ferland A, et al. Derivation of a PIRO scores for prediction of mortality in surgical patients with intra-abdominal sepsis. Am $J$ Crit Care. 2018;27:287-294. doi:10.4037/ajcc2018576

\section{Publish your work in this journal}

Pediatric Health, Medicine and Therapeutics is an international, peerreviewed, open access journal publishing original research, reports, editorials, reviews and commentaries. All aspects of health maintenance, preventative measures and disease treatment interventions are addressed within the journal. Practitioners from all disciplines are invited to submit their work as well as healthcare researchers and patient support groups. The manuscript management system is completely online and includes a very quick and fair peer-review system. Visit http://www.dovepress.com/testimonials.php to read real quotes from published authors. 